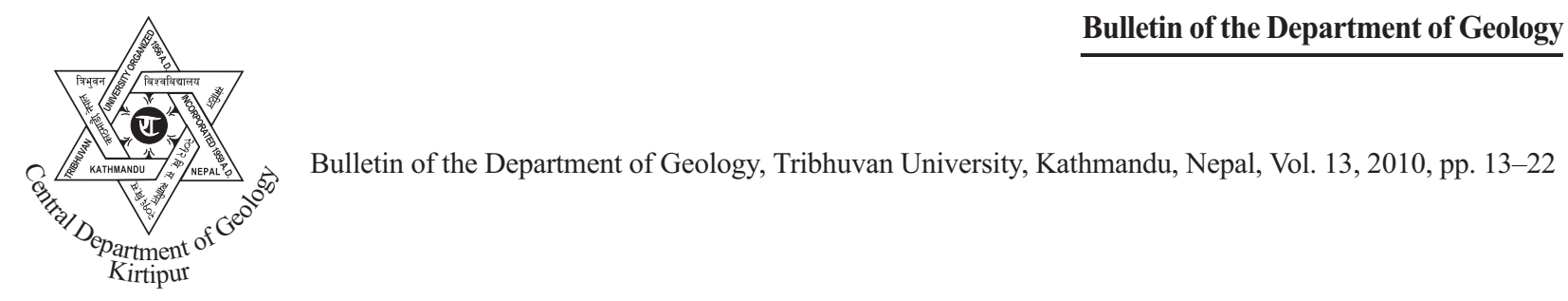

\title{
River bio-engineering solution for protecting banks and rehabilitating stream function; models for Bishnumati River, Kathmandu
}

\author{
Naresh Kazi Tamrakar \\ Central Department of Geology, Tribhuvan University, Kathmandu, Nepal
}

\begin{abstract}
Rivers of Kathmandu are deteriorating progressively and are losing natural functions. Rehabilitation of these rivers is required immediately. Recognition of river dynamics is the principal step before implementing rehabilitation works. River bio-engineering is the most appropriate way not only to establish riparian buffer zone but also to stabilise river banks from erosion and failure. The Bishnumati River, one of the major tributaries of the Bagmati River in Kathmandu was studied. Six bio-engineering models and various techniques in each of the models have been suggested to rehabilitate the functions of the river. These models are environmental friendly using local resources of natural gravels, bamboos, and plant cuttings, and incorporating minimum structural works. If properly implemented, the bio-engineering methods will be fruitful in improving river habitat as well as the recreational function.
\end{abstract}

\section{INTRODUCTION}

Rivers of urban area like Kathmandu are deteriorating day by day not only because of natural phenomena, but also because of significant disturbances caused by human beings (Tamrakar, 2004a and 2004b; Bajracharya and Tamrakar, 2007; Shrestha and Tamrakar, 2007). To retard the current trent of deterioration, workplans should be implemented to rehabilitate rivers of Kathmandu. Recognition of river dynamics is the crucial step before any rehabilitation works are undertaken. River bio-engineering (also called soil bioengineering) is the best way to reestablish riparian vegetation in highly disturbed urban rivers like the Bagmati River and its tributaries. The present study introduces some models and techniques of river bioengineering, which are suitable for rivers of Kathmandu, and are particularly proposed for the Bishnumati River as an example study.

\footnotetext{
*Corresponding author:

E-mail address: ntamrakar@hotmail.com
}

\section{BISHNUMATI RIVER BASIN}

The Bishnumati River basin is bounded between lattitude $27^{\circ} 41^{\prime} 30^{\prime \prime} \mathrm{N}$ and $27^{\circ} 48^{\prime} 30^{\prime \prime} \mathrm{N}$, and longitude $85^{\circ} 14^{\prime} 00^{\prime \prime} \mathrm{E}$ and $85^{\circ} 22^{\prime} 30^{\prime \prime} \mathrm{E}$, and is one of the major sub-basins of the Bagmati River. The summit of the Shivapuri Range $(2300 \mathrm{~m})$ forms the highest altitude of the basin whereas the river flood plain with elevation $1280 \mathrm{~m}$ is the lowest region. The northern and western regions forming mountain ranges border the Bishnumati River basin and form high relief areas with steeper slopes compared to central and eastern regions which are characterized by flat and wide older terraces and flood plains.

The Bishnumati River originates from the NW of the Kathmandu valley and flows towards south contributing the Bagmati River at Teku area (Fig. 2). Drainage areas, which contribute third, forth, fifth and sixth order segments of the Bishnumati River are respectively, 5.09, 10.78, 18.33, and 67.89 $\mathrm{km}^{2}$. The total drainage area of the basin is 102.09 $\mathrm{km}^{2}$. The overall drainage pattern in the Bishnumati river basin is dendritic. 


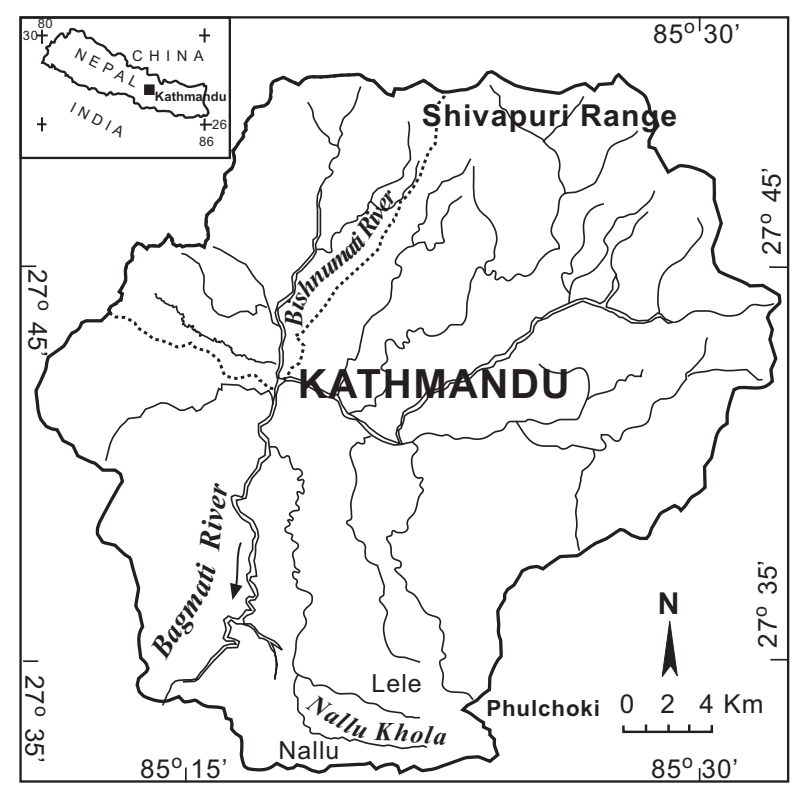

Fig. 1 A map showing the Bishnumati watershed

\section{Hydro-meteorology}

Monthly discharge recorded during 1969-1985 in Budhanilkantha station (DHM, 1998), located east of the Bishnumatigau in the northern part of the Bishnumati watershed, was analysed. The extreme maximum discharge varied between 1.040 and $3.400 \mathrm{~m}^{3} / \mathrm{s}$. The extreme min. discharge remained below $0.028 \mathrm{~m}^{3} / \mathrm{s}$. A lean flow occurs in December, January and February, whereas high flows occur in July, August and September (Fig. 3). The record of extreme max. discharge exhibits that the least discharge occurs in February and the greatest discharge occurs in August.

The maximum and the minimum average rainfalls occured respectively in July $(559 \mathrm{~mm})$ and in November ( $8.65 \mathrm{~mm}$ ) (Fig. 4). Generally, June, July and August are the periods which experience high rainfall. November, December and January experience low rainfall.

\section{EXISTING CONDITION OF RIVER}

The Bishnumati River is a sixth order stream, which has a total length of $18.4 \mathrm{~km}$ of which, first to sixth order stream stretches have lengths of 0.19 $\mathrm{km}, 0.90 \mathrm{~km}, 2.27 \mathrm{~km}, 7.95 \mathrm{~km}, 0.89 \mathrm{~km}$ and 6.17 $\mathrm{km}$, respectively. The mainstem river is sinuous with sinuosity varying from 1.15 to 1.34 . Existing

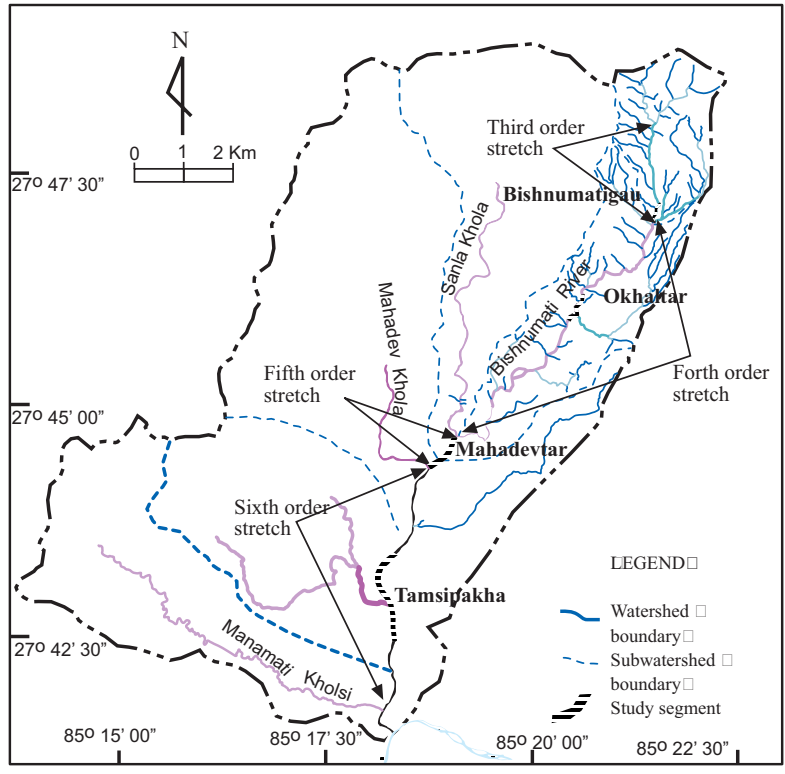

Fig. 2 The Bishnumati River basin showing major drainages and order of stream stretches along the river corridor; minor drainages are omitted for clearity

conditions of the third to sixth order stream stretches were evaluated by Tamrakar (2004a) and Adhikary and Tamrakar (2007), and are briefly accounted.

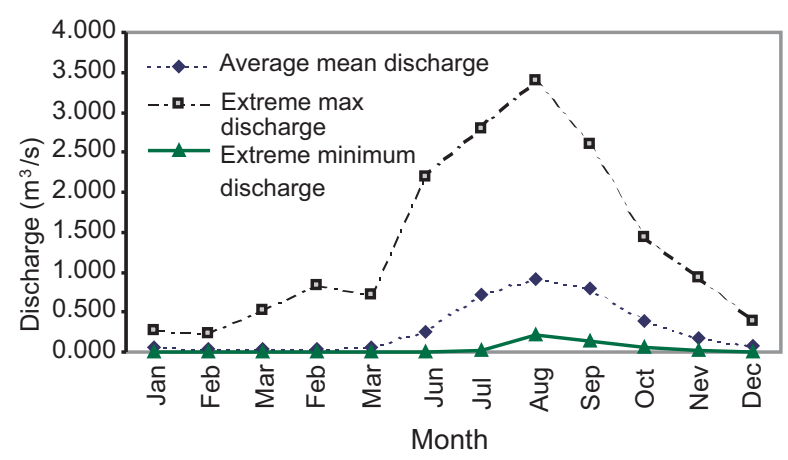

Fig. 3 Monthly average mean, extreme maximum and extreme minimum discharges during 1969-1985

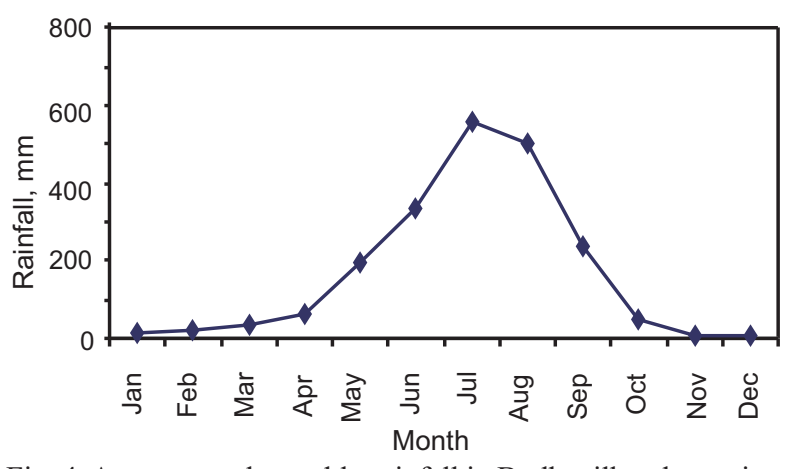

Fig. 4 Average total monthly rainfall in Budhanilkantha station during 1987-2003 


\section{Third order stream}

The third order stream is a low sinuosity stretch $(\mathrm{K}=1.15)$ with mean meander wavelength ratio (MLR) of 12.2-83.5 and mean meander belt width ratio (MWR) of 29.6 (Table 1). The mean depth at bankfull is $0.58 \mathrm{~m}$. The entrenchment ratio (ER) varies from 1.17 to 1.38 , whereas width/depth ratio (W/D ratio) varies from 7.27 to 15.2. The bank height ratio (BHR) ranges from 1.33 to 3.33 . The maximum depth ratio (MDR) varies from 1.32 to 2.17. The slope of the channel is $0.133 \mathrm{~m} / \mathrm{m}$.

The third order stream is considerably entrenched with relatively low W/D ratio, which is about half of that of the fifth order and sixth order streams. Sinuosity is also low compared to other stream stretches. The substrate is composed of pebbles to huge mega boulders along with mixture of sand. The representative third order stream stretch exhibits A4-type stream (Table 2) according to the classification of Rosgen (1994).

The third order stream has few point bars and side bars of sand and gravel. Streambanks are mostly covered with megaboulders as armours (Fig. 5). Riparian vegetation is continuous to some extent and is relatively in good condition compared to the other downstream stream stretches. The streambanks are lined up with mostly shrubs and grass, and few trees. Some banks are steep with high bank height, and scanty armour of boulders (Fig. 5). The stream is vertically unstable due to high entrenchment $(<1.4)$ and highly unstable BHR $(>1.5)$, and therefore poses high risk of degradation. MWR is moderate and bank erosion hazard index (BEHI) is also moderate (29.6). W/D ratio is considerably larger showing moderate lateral instability of the stream.

\section{Forth order stream}

The forth order stream is a sinuous stretch $(\mathrm{K}=$ 1.34) with MLR of 31.3 and MWR of 70.4 (Table 1). The bankfull cross-sectional area and the mean depth at bankfull are 4.89 square metres and 0.64 $\mathrm{m}$, respectively. ER varies from 2.29 to 12.2 while W/D ratio varies from 8.09 to 20.3. BHR and MDR are 1.67-2.11 and 1.20-2.01, respectively. The slope of the channel is $0.008 \mathrm{~m} / \mathrm{m}$.

The forth order stream stretch is the least entrenched stretch (4.78). It has W/D ratio greater than 12 and sinuosity of 1.34 . These parameters are lesser than thoese required for an E-type stream. The stretch possesses low slope angle $(0.008 \mathrm{~m} / \mathrm{m})$ and contains pebble sized sediments. The forth order

Table 1: Morphological data from segments of the Bishnumati River

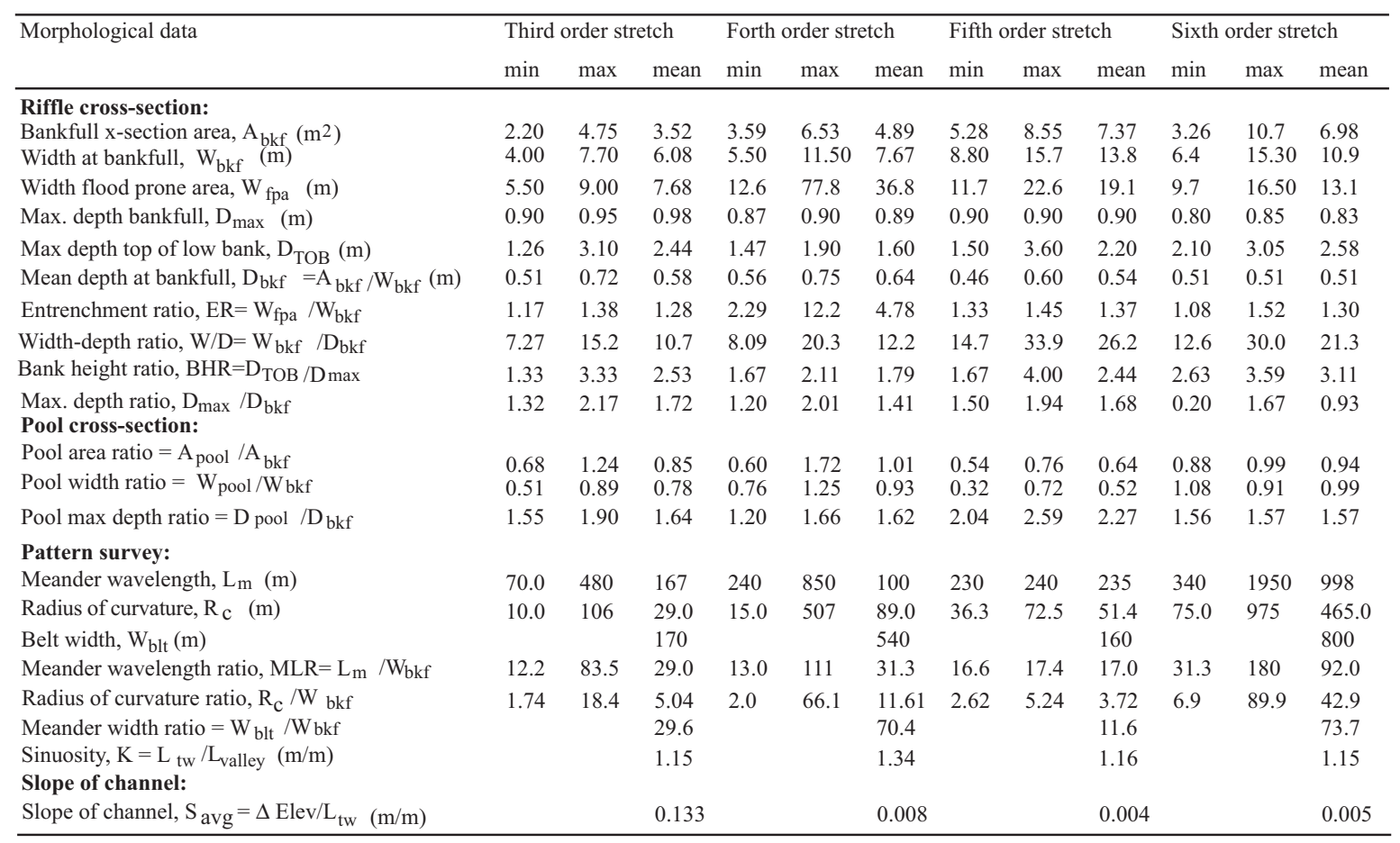


(a)

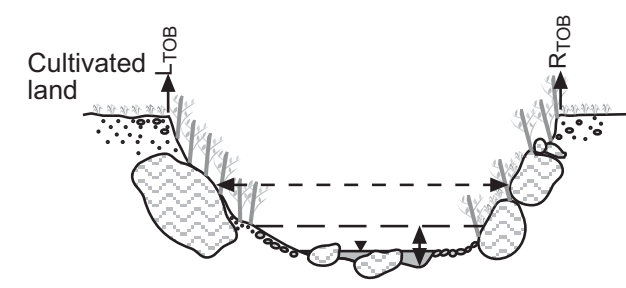

(b)
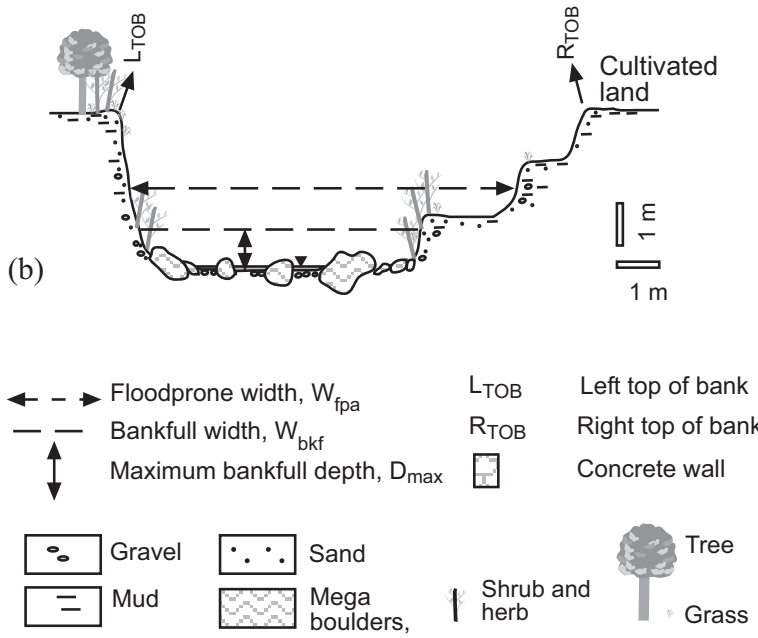

Fig. 5 Cross-sections of transects in Bishnumatigau segment; From downstream section (a) to the upstream section (e)

stream stretch is categorized as a C4-type stream (Table 2).

The forth order stream has several point bars and side bars of sand and gravel. Stream cross-sections have generally wider floodprone width than the bankfull width (Fig. 6). Average depth does not vary much with max. bankfull depth. Streambanks are mostly composed of interlayering of sandy gravel, sand and silt. Substrate materials are abundantly gravel and sand. The lower banks are mostly eroded. Bank erosion by parallel and impinging flows is common. The landuse at both right and left streambanks is cultivation. In downstream segments of the forth order stream the right banks are subject to excavation for sand. The abandoned excavation sites have high bank heights and some of which have experienced small landslides.

Riparian vegetation is discontinuous and occurs linearly. It consists of few linear trees with scattered shrubs and grasses. It is even weaker in the downstream segments compared to the upstream ones.

Forth order stream is non-entrenched and has low degradation potential. MWR is low and BEHI is high (29.6). As BHR is $>1.5$, some banks particularly located at cutbanks are vulnerable to flow erosion and mass movement, and therefore are laterally unstable. W/D ratio is also considerably larger (12.2) showing moderate lateral instability of stream.

\section{Fifth order stream}

MLR and MWR of fifth order stream are $16.6-17.4$ and 11.6, respectively (Table 1 ). It's bankfull cross-sectional area varies from 4.89 to

Table 2: Summary of Rosgen stream classification of the Bishnumati River

\begin{tabular}{lllll}
\hline & $\begin{array}{l}\text { Third order } \\
\text { stretch }\end{array}$ & $\begin{array}{l}\text { Forth order } \\
\text { stretch }\end{array}$ & $\begin{array}{l}\text { Fifth order } \\
\text { stretch }\end{array}$ & $\begin{array}{l}\text { Sixth order } \\
\text { stretch }\end{array}$ \\
\hline Morphological parameters & 3.52 & 4.89 & 7.37 & 6.98 \\
Bankfull x-section area, $\mathrm{A}_{\mathrm{bkf}}\left(\mathrm{m}^{2}\right)$ & 6.10 & 7.67 & 13.8 & 10.85 \\
Width at bankfull, $\mathrm{W}_{\mathrm{bkf}}(\mathrm{m})$ & 7.68 & 36.80 & 19.05 & 13.10 \\
Width flood prone area, $\mathrm{W}_{\mathrm{fpa}}(\mathrm{m})$ & 0.98 & 0.89 & 0.90 & 0.83 \\
Max. depth bankfull, $\mathrm{D}_{\max }(\mathrm{m})$ & 0.58 & 0.64 & 0.54 & 0.51 \\
Mean depth at bankfull, $\mathrm{D}_{\mathrm{bkf}}=\mathrm{A}_{\mathrm{bkf}} / \mathrm{W}_{\mathrm{bkf}}(\mathrm{m})$ & $1.28(\mathrm{~A})$ & $4.78(\mathrm{C}, \mathrm{E})$ & $1.37(\mathrm{~F}, \mathrm{G})$ & $1.30(\mathrm{~F}, \mathrm{G})$ \\
Entrenchment ratio, $\mathrm{ER}=\mathrm{W}_{\mathrm{fpa}} / \mathrm{W}_{\mathrm{bkf}}$ & $10.69(\mathrm{~A}, \mathrm{E}, \mathrm{G})$ & $12.19(\mathrm{C})$ & $26.16(\mathrm{~F}, \mathrm{C})$ & $21.29(\mathrm{C}, \mathrm{F})$ \\
Width-depth ratio, $\mathrm{W} / \mathrm{D}=\mathrm{W}_{\mathrm{bkf}} / \mathrm{D}_{\mathrm{bkf}}$ & $1.15(\mathrm{~A})$ & $1.34(\mathrm{C}, \mathrm{F})$ & $1.16(\mathrm{~F}, \mathrm{E})$ & $1.15(\mathrm{C}, \mathrm{F}, \mathrm{G})$ \\
Sinuosity, $\mathrm{K}$ & $0.133(\mathrm{~A})$ & $0.008(\mathrm{~F}, \mathrm{E}, \mathrm{C})$ & $0.004(\mathrm{~F}, \mathrm{E}, \mathrm{C})$ & $0.005(\mathrm{~F}, \mathrm{E}, \mathrm{C})$ \\
Slope $(\mathrm{m} / \mathrm{m})$ & $27.86(\mathrm{pebble})$ & $3.73(\mathrm{pebble})$ & $0.87(\mathrm{sand})$ & $25.11(\mathrm{pebble})$ \\
Dominant channel material, $\mathrm{D}_{50}(\mathrm{~mm})$ & $\mathrm{A} 4$ & $\mathrm{C} 4$ & $\mathrm{~F} 5$ & $\mathrm{~F} 4$ \\
Rosgen stream type & & & & \\
Hydraulic parameters & & 0.55 & 0.49 & 0.59 \\
Hydraulic radius, $\mathrm{R}=\mathrm{A}_{\mathrm{bkf}} /\left(2 \mathrm{D}_{\mathrm{bkf}}+\mathrm{W}_{\mathrm{bkf}}\right)(\mathrm{m})$ & 0.48 & 0.031 & 0.038 & 0.033 \\
Manning's roughness coefficient, $\mathrm{n}$ & 0.280 & 9.47 & 7.70 & 10.53 \\
Bankfull discharge, $\mathrm{Q}=1 . \mathrm{A} . \mathrm{R}^{2 / 3} \cdot \mathrm{S}^{1 / 2},\left(\mathrm{~m}^{3} / \mathrm{s}\right)$ & 2.84 & 1.94 & 1.05 & 1.51 \\
Bankfull velocity, $\mathrm{V}=\mathrm{Q} / \mathrm{A}_{\mathrm{bkf}}(\mathrm{m} / \mathrm{s})$ & 0.81 & & & \\
\hline
\end{tabular}




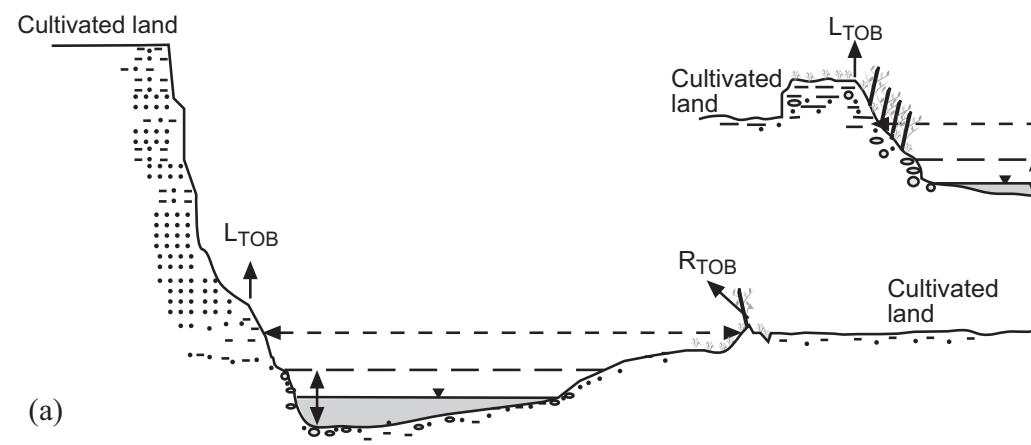

Fig. 6 Cross-sections of transects of the forth order stream stretch: (a) Cross-section at pool with high bank height, and (b) Crosslsection of riffle with wide flood prone area (see Fig. 9 for legend)

5.28 square metres, whereas mean depth at bankfull varies from 0.46 to $0.60 \mathrm{~m}$. BHR lies between 1.67 $\mathrm{m}$ and $4.00 \mathrm{~m}$. MDR ranges from 1.50 to 1.94 .

The fifth order stream shows lower ER (1.37) and higher W/D ratio (26.16) compared to the forth order stream suggesting higher entrenchment with considerably larger width compared to depth. Sinuosity does not exceed 1.2. Slope of channel also diminishes from 0.008 to $0.004 \mathrm{~m} / \mathrm{m}$. The dominant riverbed material is sand although there exists gravel and clay. The substrate is often clayey in pools and sandy on riffles. Gravel and sand layers are stratified and characterize bank materials (Fig. 7).Therefore this stream stretch is classified as F5-type stream (Table 2).

The stream stretch comprises few mid-channel bars, side bars and point bars. In dowstream segment, stream rarely comprises bars but incises channel. Bank erosion scars are also well developed indicating active bank erosion. Parallel and impinging flow erosion is frequent. No major slope failure is observed. However channel bed scouring and generation of deep pools is notable.

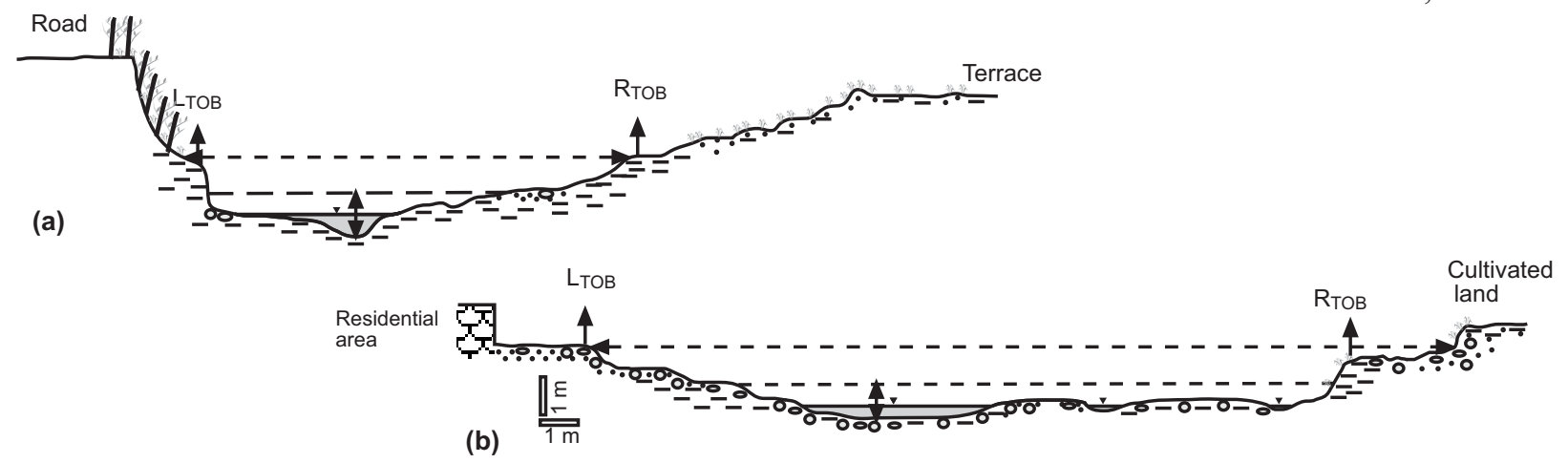

Fig. 7 Cross-sections of transects of the fifth order stream stretch: (a) Cross-section of pool, and (b) Cross-section of riffle
Riparian vegetation consists of few shrubs and mostly grasses (Fig. 7) and serves for narrow zone and sometimes for patches. Riparian vegetation is the poorest among the stream stretches because of extreme human disturbances in this stretch. Remarkable disturbances recorded include vegetation clearing, channel constriction, and encroachment for shelter and building roads are remarkable activities. The landuse at riverbanks is comprises settlement and cultivation.

The fifth order stream is entrenched with highly unstable bank height ratio (2.44). Laterally this stream stretch is unstable in terms of high W/D ratio, but compared to the other stretches its low MWR exhibits high lateral stability. BEHI is high as in forth and sixth order stretches.

\section{Sixth order stream}

The sixth order stream is a low sinuosity stretch $(\mathrm{K}=1.15)$. MLR and MWR are 31.3-180 and 73.7, respectively. RCR ranges from 6.9 to 89.9. It's bankfull cross-sectional area ranges from 3.26 to 10.7 square metres, whereas mean depth at bankfull is $0.51 \mathrm{~m}$. ER varies from 1.08 to 1.52 , whereas 
W/D ratio varies from 12.6 to 30 . BHR lies between $2.63 \mathrm{~m}$ and $3.59 \mathrm{~m}$. MDR ranges from 0.20 to 1.67 . The slope of the channel is $0.005 \mathrm{~m} / \mathrm{m}$.

The channel is entrenched with high W/D ratio and very low sinuosity. The channel slope is very low and the substrate material is pebble, although clay and sand are also present. Therefore this stretch is classified as F4-stream (Table 2).

The stream stretch comprises side, mid and point bars compasing sand and gravel. The bank material dominantly consist of a solid waste filled over the strata of sand and clay. The solid wastes are inturn covered with gravel for extending roads (Fig. 8).

Riparian vegetation comprises few shrubs and grasses, and rarely trees (Fig. 8). Trees are rare. Most of the vegetation has been cleared off. Few native vegetation grows but no systematic protection of banks using vegetaion has been applied over the solid waste. Therefore, Bank scouring often exists. However major slope failure occurs. Scouring however undercuts bank materials and causes collapse of overlying fill materials. At several places banks have been linned up with gabion wallsfor the protection.

The sixth order stream is vertically unstable due to its high bank height and entrenched nature. MWR is relatively low. BEHI is very high because of unprotected slopes and loose unstratified bank material fillings. High W/D ratio also shows lateral instability of banks. High bank erosion potential shows lateral instablility though the river has degrading potential. Shumm's F-M plots indicate that all the stream stretches of the Bishnumati River lie in degrading field (Adhikari and Tamrakar, 2007).

\section{BIO-ENGINEERING TECHNIQUES AND SUGGESTED MODELS}

Streambank bio-engineering has broadly twofold functions: (a) stabilization of banks from mass wasting and (b) establishment of riparian vegetation to create and maintain ecosystem and canopy, and to retard pollution.

Streambank vegetation should be established to reduce erosion. Vegetation has several benefits to river. It protects banks from pollution and erosion, improves ecosystem and generates recreational area which can be used benificially for benefit of people. Such vegetation zone works as a barrier to various contaminants and licheates from waste dumps or from agricultural and industrial fields, which otherwise cause deterioration of river habitat.

Establishment of riparian vegetation requires consideration of streambanks vegetation depending on functions of vegetations. These are overstorey, understorey and ground cover. The overstorey vegetation comprises tall trees which give large
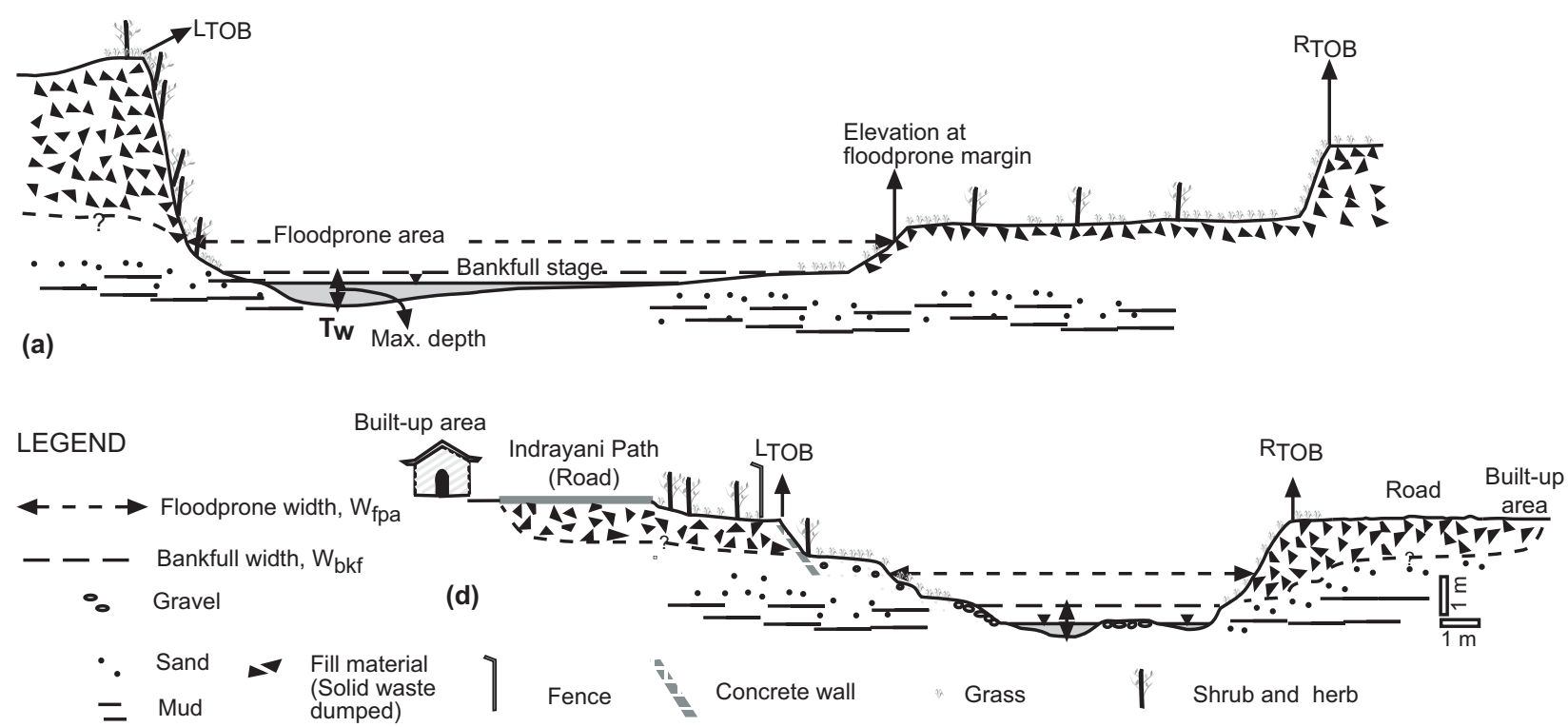

Fig. 8 Cross-sections of transects of the sixth order stream stretch: (a) Cross-section of pool, and (b) Cross-section of riffle 
interception and canopy to river. The understorey vegetation comprises little trees and shrubs which anchor and protect soil by intercepting rain water. The ground cover consists of shrubs and herbs together with leaf litters, and its function is to protect soil from direct impact of rain water. Placement of vegetation can be distinguished by position of banks, e.g., upper bank area that extends from the lower top of the bank to the upslope, and lower bank area.

Selection of bio-engineering techniques depends on the (a) morphology of the river and banks, (b) stability condition of the river, and (c) functions required to be fulfilled for stabilization of slope and establishment of vegetation zone. Table 3 lists suggested models for river bio-engineering based on the above mentioned criteria and some techniques (Howell, 1999).

\section{Model 1}

The model 1 is suggested for the third order stream stretch in which the stream is entrenched with moderate to high bank height but with huge amount of boulder armours over the banks, thus protecting the banks (Fig. 9). Only the function required is anchoring of the upper bank region where bank vegetation is partly destroyed by cultivation. Therefore planting huge trees and bamboos in the upper bank functions both for anchoring and for establishing canopy to stream. The techniques suggested for the upper banks are pole and bamboo

Table 3 Models proposed for application of bio-engineering techniques to the streambanks of the Bishnumati River

\begin{tabular}{|c|c|c|c|c|c|}
\hline Model & $\begin{array}{l}\text { River } \\
\text { morphology }\end{array}$ & Bank features & $\begin{array}{l}\text { Functions } \\
\text { required }\end{array}$ & Techniques & Remarks \\
\hline 1 & $\begin{array}{l}\text { Entrenched }(1.28) \\
W / D \text { ratio }=10.69 \\
\mathrm{~K}=1.15 \\
\mathrm{MWR}=29.6\end{array}$ & $\begin{array}{l}\text { Moderate to high bank } \\
\text { height with natural armouf } \\
\text { of mega boulders; } \\
\text { Moderate lateral instability }\end{array}$ & $\begin{array}{l}\text { Anchoring of } \\
\text { upper bank soil }\end{array}$ & $\begin{array}{l}\text { Pole planting Bamboo planting } \\
\text { of upper banks, shrubs as } \\
\text { understorey }\end{array}$ & $\begin{array}{l}\text { Applicable to } \\
\text { 3rd order } \\
\text { stream }\end{array}$ \\
\hline 2 & $\begin{array}{l}\text { Entrenched }(1.28) \\
W / D \text { ratio }=10.69 \\
\mathrm{~K}=1.15 \\
\mathrm{MWR}=29.6\end{array}$ & $\begin{array}{l}\text { Relatively very high bank } \\
\text { height with unprotected } \\
\text { banks, gravelly and } \\
\text { bedrock banks; Moderate } \\
\text { lateral instability }\end{array}$ & $\begin{array}{l}\text { Anchoring of upper } \\
\text { bank soil, protection } \\
\text { cover, and erosion } \\
\text { control for lower } \\
\text { banks }\end{array}$ & $\begin{array}{l}\text { Pole planting Bamboo planting } \\
\text { of upper banks, shrubs as } \\
\text { understorey, boulder and tree } \\
\text { rootwad revetment at lower } \\
\text { banks }\end{array}$ & $\begin{array}{l}\text { Applicable } \\
\text { to 3rd order } \\
\text { stream }\end{array}$ \\
\hline 3 & $\begin{array}{l}\text { Entrenched }(1.37) \\
W / D \text { ratio }=26.16 \\
\mathrm{~K}=1.16 \\
\mathrm{MWR}=11.6\end{array}$ & $\begin{array}{l}\text { Cutbanks and pool with } \\
\text { moderate bank height and } \\
\text { riffles with low bank height; } \\
\text { bank material: sand and gravel } \\
\text { underlain by clay; low lateral } \\
\text { instability }\end{array}$ & $\begin{array}{l}\text { Reducing scouring } \\
\text { and erosion, surface } \\
\text { protection and } \\
\text { providing cannopy }\end{array}$ & $\begin{array}{l}\text { Pole planting, Staking, brush } \\
\text { layering in upper banks, Wattle } \\
\text { fences or ravetment system at } \\
\text { lower banks }\end{array}$ & $\begin{array}{l}\text { Applicable to } \\
5 \text { th order } \\
\text { stream }\end{array}$ \\
\hline 4 & $\begin{array}{l}\text { Entrenched }(1.30) \\
W / D \text { ratio }=21.29 \\
\mathrm{~K}=1.15 \\
\mathrm{MWR}=73.7\end{array}$ & $\begin{array}{l}\text { Riffles with mod. to high bank } \\
\text { height Pools with high bank } \\
\text { height, channelised stream with } \\
\text { fill material; banks are } \\
\text { unprotected, high bank erosion } \\
\text { hazard; High lateral instability }\end{array}$ & $\begin{array}{l}\text { Bank slope retaining } \\
\text { and shielding from } \\
\text { contamination of } \\
\text { waste dump, surface } \\
\text { protection, erosion } \\
\text { control, canopy }\end{array}$ & $\begin{array}{l}\text { Live palisades, vegetated } \\
\text { gabions, staking of cuttings, } \\
\text { brush layering; tree planting in } \\
\text { upper banks to meet canopy } \\
\text { function, lower banks should be } \\
\text { benched for brush layering along } \\
\text { with staking }\end{array}$ & $\begin{array}{l}\text { Applicable } \\
\text { to } 6 \text { th order } \\
\text { stream }\end{array}$ \\
\hline 5 & $\begin{array}{l}\text { Non-entrenched } \\
(4.78) \\
W / D \text { ratio }=12.19 \\
\mathrm{~K}=1.34 \\
\mathrm{MWR}=70.4\end{array}$ & $\begin{array}{l}\text { Riffles and pools with low bank } \\
\text { height, high lateral instability, } \\
\text { bank material: sandy gravel or } \\
\text { gravelly sand }\end{array}$ & $\begin{array}{l}\text { Reinforcement, } \\
\text { anchorage, } \\
\text { armouring and toe } \\
\text { protection; canopy }\end{array}$ & $\begin{array}{l}\text { Pole planting, staking, brush } \\
\text { layering of understorey, wattle } \\
\text { fencing and vegetative riprap } \\
\text { armouring of the lower bank }\end{array}$ & $\begin{array}{l}\text { Applicable } \\
\text { to } 4 \text { th order } \\
\text { stream }\end{array}$ \\
\hline 6 & $\begin{array}{l}\text { Non-entrenched } \\
(4.78) \\
W / D \text { ratio }=12.19 \\
\mathrm{~K}=1.34 \\
\mathrm{MWR}=70.4\end{array}$ & $\begin{array}{l}\text { Pools with high bank height } \\
\text { and steep bank angle, bank } \\
\text { material: sandy gravel or } \\
\text { gravelly sand; moderate lateral } \\
\text { instability }\end{array}$ & $\begin{array}{l}\text { Retaining, anchoring, } \\
\text { reinforcement, } \\
\text { armouring and toe } \\
\text { protection; canopy }\end{array}$ & $\begin{array}{l}\text { Pole planting and live staking at } \\
\text { upper slope; bamboo at lower } \\
\text { part, brush mattressing, crib or } \\
\text { vegetated gabion with geotextile } \\
\text { if needed; ravetment system }\end{array}$ & $\begin{array}{l}\text { Applicable } \\
\text { to } 4 \text { th order } \\
\text { stream }\end{array}$ \\
\hline
\end{tabular}




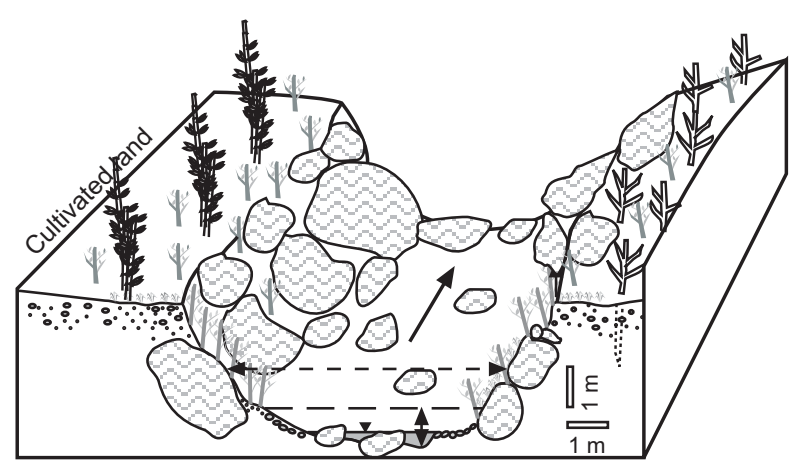

Fig. 9 River bio-engineering model 1 for third order reach, which is entrentched stream with presence of natural armour

planting as overstorey and shrubs as understorey.

\section{Model 2}

The model 2 applies to the third order stream stretch where bank height is relatively high and lack natural protection of armour. The upper bank requires anchorage which can be met by pole planting of trees or planting of bamboos (Fig. 10). Understorey vegetation should consist of shrubs. Soil protection cover may be achieved by ground cover by mattressing of non-woody plants. The lower bank should be protected from erosion. Because of high gradient of the river, erosive power in this stretch is notable. The toe erosion can be controlled by applying combination of tree rootwad and boulder ravetment (Fig. 10), because both of these materials are easily availabe in the third order stream stretch.

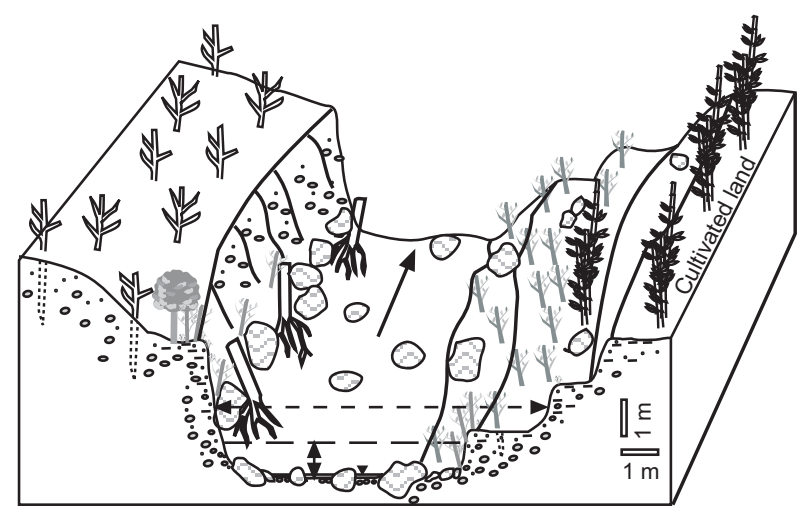

Fig. 10 River bio-engineering model 2 for third order reach, which is entrentched stream without sufficient armour

\section{Model 3}

Model 3 is suggested for fifth order stream stretch which is entrenched with moderate bank height in case of pools and with low bank height in case of riffle. Bank materials are composed of sand and gravel underlain by thick black clay. In fifth order stream, scouring is notable. Surface protection is also low and therefore active bank erosion happens. Riparian vegetation is very poor in this stretch. Armouring the banks for surface protection, toe protection, reinforcement of bank material, and establishment of riparian vegetation are some of the major functions required to be met. The upper banks are treated with pole planting to establish riparian vegetation (Fig. 11). This zone consists of shrubs as understorey and brush layering of grass for ground cover. The lower banks are treated with live staking to provide reenforcement of soil and to generate vegetation covering. Wattle fences of bamboo can

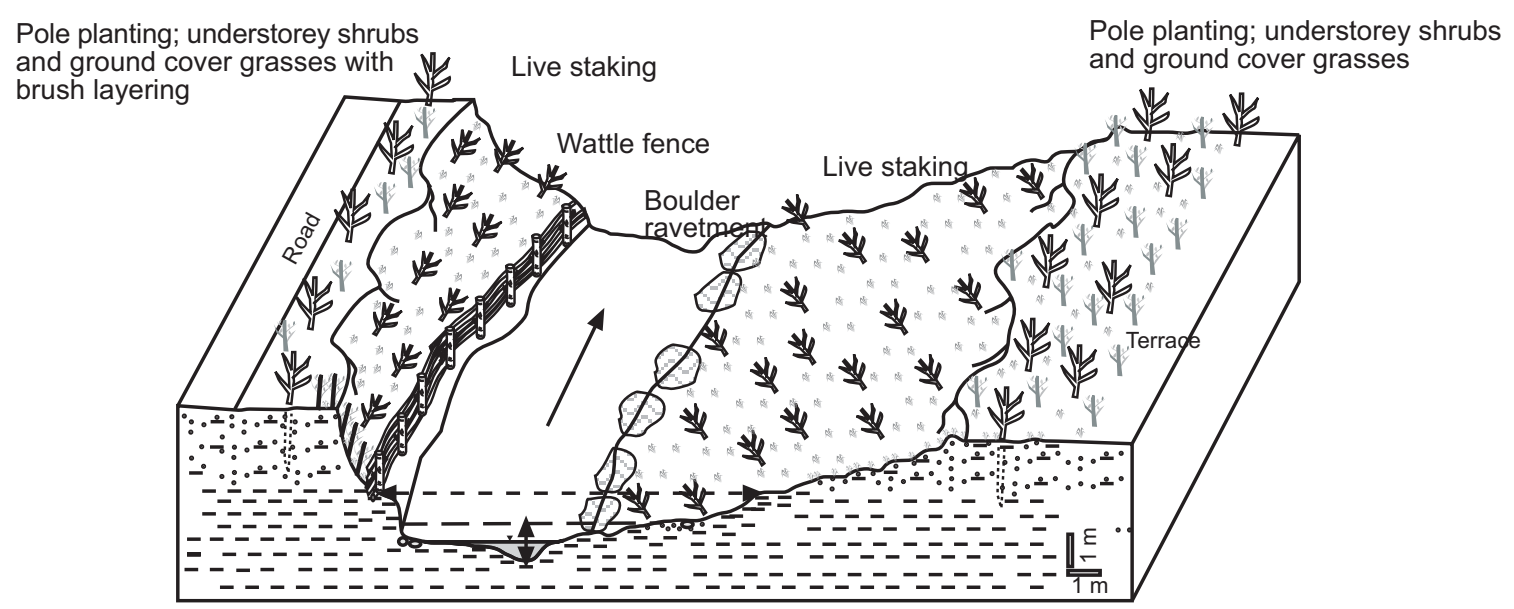

Fig. 11 Model 3 applicable to fifth order stream stretch 
be constructed in the lower part of the steep slopes to create buffer zone, retain the erodible soil, and prevent toe from erosion. Wattle fences may used in combination with riprap. The toe of the low angle slopes may be protected using ravetment system (Fig. 11). Boulder ravetment is suitable because it is available nearby. Tree ravetment would be expensive.

\section{Model 4}

Model 4 is suggested for sixth order stream stretches with high bank height. This stretch is laterally unstable with high BEHI potential. Lateral erosion and toe cutting are notable. The bank material is loose, fill material of solid waste dumped to extend road along the both banks of the river. Where toe erosion is pronounced with steep and high bank height, construction of retaining wall is recommended to prevent contamination of waste to the river and for retarding toe erosion and stabling the slope (Fig. 12a). Back of the retaining walls is constructed brush layers to cover the slope. For canopy, the upper bank is vegetated using live palisade technique, because the bank material is solid waste. Live palisade is accompanied with understorey shrubs and ground cover of grasses. The areas between live palisade and road may be used for recreational park. The plants used for live palisade can be of various fruits.

Model 4 can be slightly modified by replacing retaining walls by riprap toe protection (Fig. 12b). Because the bank height is moderate and angle is not very steep, retaining function is not required in this case. Toe protection is however needed and therefore ripraps are used.

\section{Model 5}

Model 5 is suggested for the forth order stretch with riffles and pools which have low bank height, low entrenchment ratio, high lateral instability, and sandy gravel or gravelly sand bank material. Apart from canopy function, reinforcement of of bank material, anchorage and armouring functions are required. The upper portion of the banks are anchored using pole planting of trees (Fig. 13). Shrubs and grasses are used in this region to make up understorey and ground cover. The slopes facing the stream are planted with shrubs applying staking method. Clumping grasses are used in combination with shrubs for vegetative armour. Protection of toe is also required as impinging flow creats cantilever banks in this stretch. For the toe protection wattle fence and riprap toe armouring are suitable techniques.

(a)
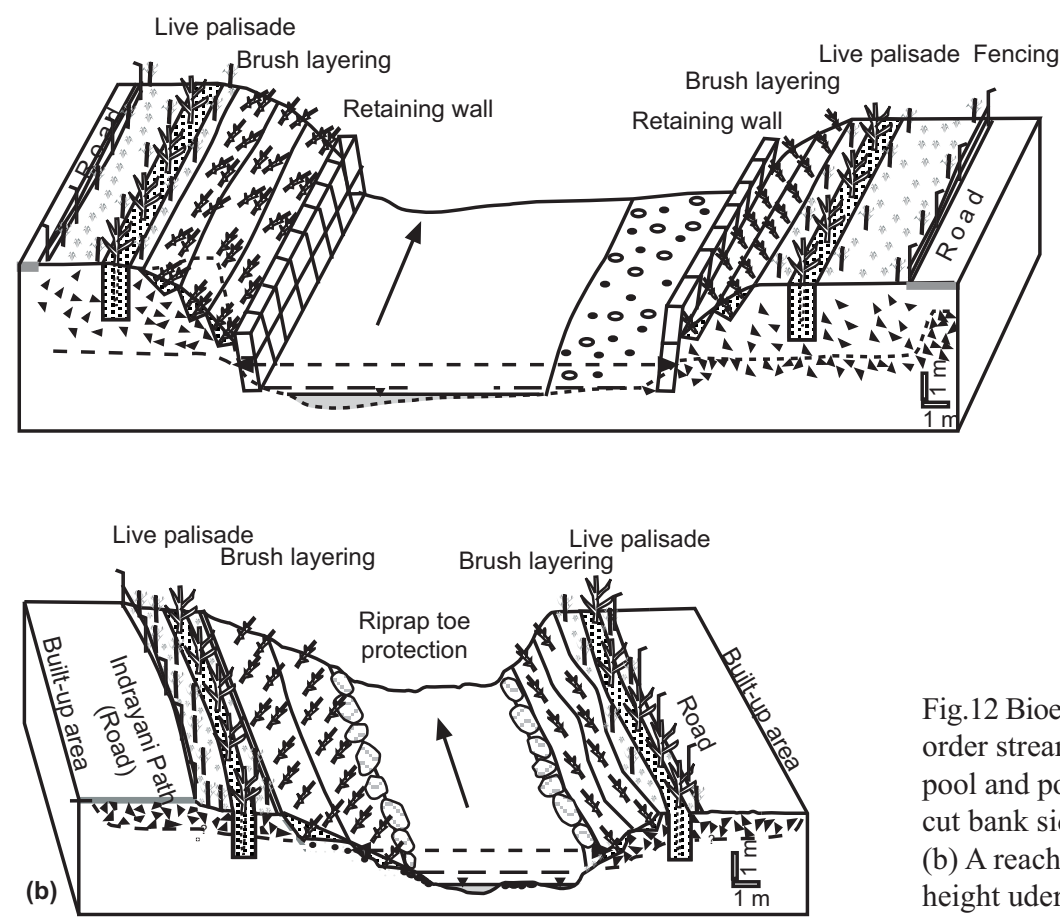

Fig.12 Bioengineering Model 4 for sixth order stream stretch: (a) A reach with pool and point bar, high bank height at cut bank side undergoing toe erosion, (b) A reach with riffle and high bank height udergoing erosion 


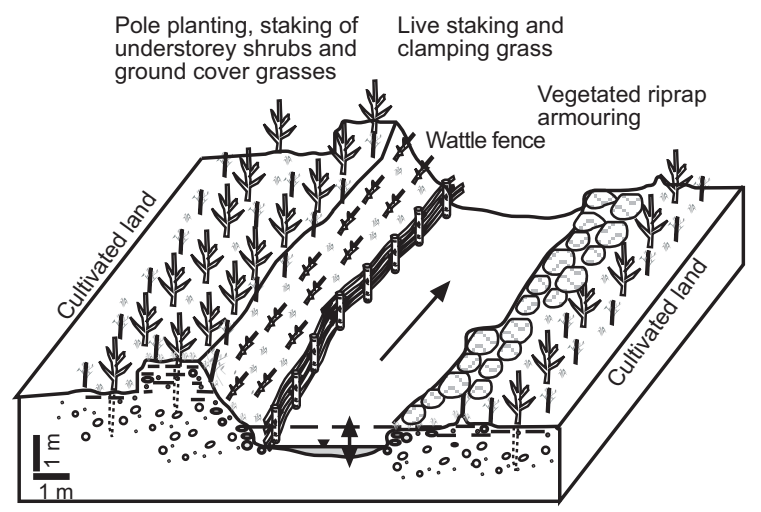

Fig. 13 Model 6 applicable to forth order stream stretch with low bank height

\section{Model 6}

The reaches of the forth order stretch, which are non-entrenched, having relatively high banks and steep bank slope posing moderate lateral instability are subject to bio-engineering model 6 (Fig. 14). Because of high and steep banks, additionally the retaining function is required comapred to the model 5. Poor bank vegetation requires establishment of riparian zone. The channels are laterally unstable with their banks suffering from toe erosion and failure. In this instance, the cut bank slopes can be retained, protected from toe erosion and stabilized using vegetated gabions or crib walls (Fig. 14). Geotextile may be used to protect the lowermost slope region because the bank material is largely non-cohesive. Pole planting of trees or planting of bamboo is suggested for upper bank areas. Live staking can be applied for shrubs forming understorey. The slope face is protected and reinforced using live staking, and brush mattressing. The convex bank where retaining function is not required, can be protected using ravetment system.

\section{CONCLUSIONS}

River morphology, hydraulics, channel and bank material, erosion processes, vegetation and disturbing conditions are the preliminary parameters in categorising and recognising stream stability and existing conditions. Based on these parameters and stability conditions, six bio-engineering models are suggested for the Bishnumati River corridor. Techniques are suggested considering functions required to be met for river rehabilitation, for enhancing recreational function, and on probable

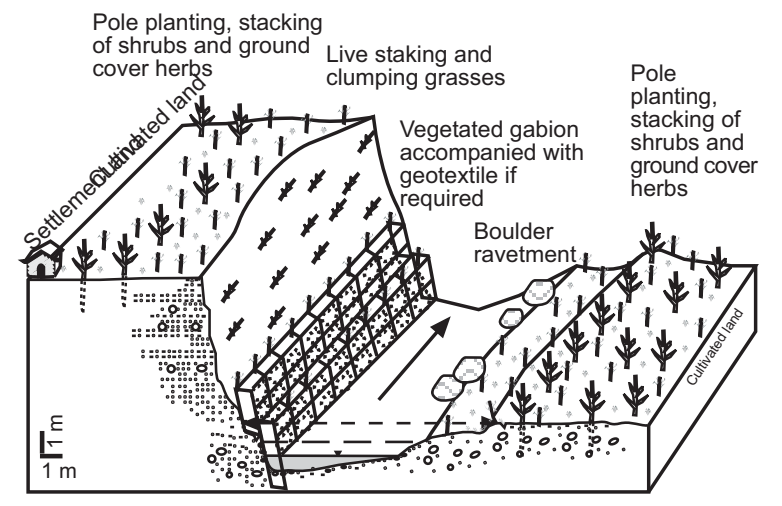

Fig. 14 Model 5 applicable to forth order stream stretch with very high and steep bank height

availability of local resource materials. In most of the cases, structural works are minimised unless required. These bio-engineering models if applied carefully, will restablish riparian vegetation, improve river ecosystem, and establish dynamic and recreational functions.

\section{REFERENCES}

Adhikari, B. and Tamrakar, N.K., 2006. Bank instability and erosion problems in Bishnumati River, Kathmandu, Nepal. Proceeding of Fifth Asian Regional Conference on Engineering Geology for Major Infrastructure Development and Natural Hazard Mitigation 28-30, 2005, Jour. Nepal Geol. Soc., Special Issue, v. 34, pp. 109-116.

Bajracharya, R. and Tamrakar, N. K., 2007. Environmental status of Manahara River, Kathmandu, Nepal. Bulletin of the Department of Geology, v. 10, pp. 21-32.

DHM, 1998, Hydro-meteorological data from the Budhanilkantha station. Electronic data from Department of Hydrology and Meteorology, Nepal Government, Babar Mahal, Kathmandu, Nepal.

Howell, J., 1999. Roadside Bio-Engineering, Reference Manual. Department of Roads, Kathmandu, Nepal, $216 \mathrm{p}$.

Rosgen, D.L., 1994. A classification of natural rivers, Cantenna, v. 22, pp. 169-199.

Shrestha, P. and Tamrakar, N.K., 2007a. Streambank erodibility and lateral instability hazard in the Manahara River, Kathmandu basin, Nepal. Journal of Nepal Geological Society, v. 35, pp. 55-66.

Tamrakar, N.K., 2004a. River degradation problems along the Bishnumati River corridor in the Kathmandu Basin. A report submitted to Human and Geoscience Group, , $37 \mathrm{p}$.

Tamrakar, N.K., 2004b. Disturbances and instabilities in the Bishnumati River corridor, Kathmandu basin, JUSAN, v.9, no. 16, pp. 7-18. 